\title{
THE DEVELOPMENT OF SCIENCE LEARNING DEVICE BASED ON SCIENCE EDUTAINMENT TO IMPROVE STUDENT'S LEARNING MOTIVATION AND COGNITIVE LEARNING ACHIEVEMENT
}

\author{
Tiffani Anggarniastiti, Dadan Rosana, Wita Setianingsih \\ Science Education, Yogyakarta State University \\ E-mail: tiiffanni22@gmail.com
}

\begin{abstract}
The aims of this research are 1) to produce science learning device based on Science Series which is feasible according to the validators, 2) to know the students ' response to Science Edutainment learning, 3) to know the improvement of students ' learning motivation after using learning device which developed, 4) to know the improvement of students ' cognitive learning achievement after using learning device which was developed. This research is categorized as $R \& D$ research with $4 d$ model (Define, Design, Develop, and Disseminate). Instruments which were used in this research are validation forms of learning device, students 'questionnaire response to Science Education learning, students ' questionnaire of learning motivation, pretest and posttest, and learning task observation form. The data analysis techniques used in this research are qualitative and quantitative. The results of this research are: 1) it has been produced science learning device based on Science Series which is feasible with excellent category (A) according to the validators, 2) science learning which used learning devices based on Science Edutainment get students' response with good category $(B), 3)$ science learning device can improve students ' learning motivation with percentage $10.74 \%$, 4) science learning device can improve students 'cognitive learning achievement with result of gain score is 0.73 and categorized as high category.
\end{abstract}

Keywords: cognitive learning achievement, learning device, motivation, science edutainment.

\section{INTRODUCTION}

The curriculum has been mandated that the 2013 model learning IPA on secondary/MTs is integrated learning model which combines the concepts of the three disciplines that is physics, biology, and chemistry. The curriculum requires learning the IPA also 2013 based on interactive, learners, developing curiosity and creativity so that learners are expected to actively conduct investigations to obtain knowledge.

Based on the results of observation on SMP N 1 Wonosari, learning the IPA yet are student centered curriculum expectations from 2013 so that learning requires the active, creative, and means has yet to be realized. As long as this is still not a lot of teachers who are able to create IPA learning a fun, interesting, and memorable for learners. In fact, a way of packaging learning experience will determine the meaningfulness of such learning. The learning process will be more meaningful if learners grasp concepts they are learning through direct observation and active learning in a fun learning atmosphere.

Based on the results of interviews with learners, IPA is still considered difficult subjects, this is evidenced by the value of Deuteronomy daily IPA which is still under the KKM. The IPA became difficult for students because of lack of motivation in learning the IPA. Observationally, the lack of motivation of learning is shown by the learners who do not focus on learning and the learner's participation is still low. One of the factors that are causing the learning motivation of learning method is less used teachers less markedly and interesting so that learners feel bored. Low learning motivation will certainly comparable with the results of the study are low anyway, particularly on cognitive aspect.

In a learning naturally required a manual in the form of a learning device. Along with the development of the educational world, certainly needed innovation in creating a learning device, namely to create a fun learning, unique, creative and goal-oriented but still. Unfortunately, not all of the learning available at school and yet the existence of innovation to develop a learning device that already exists.

Based on the background of researchers looked at the need for research to improve the motivation of learning and cognitive learning outcomes learner learning by creating fun and entertaining IPA for learners through the development of Science-based learning, Edutainment device. Therefore, researchers intend to do penleitian, entitled "Development of learning the IPA SMP-based Science Edutainment to increase the motivation of learning and Cognitive Learning Outcomes Learner".

\section{RESEARCH METHODS}

This research is research development by implementing $4 \mathrm{~d}$ model in accordance with Sivasailam, (1974: 6-9).

\section{Time and place of Research}

This research was carried out in April through may 2017 in SMP N 1 Wonosari. 


\section{The Subject of Research}

The subject in this study is the validator which consists of 2 professors and experts 2 IPA teachers and learners classes VII B SMP N 1 Wonosari of 22 children.

\section{Object of Research}

The object in this research is sluruh device learning IPA-based Science Edutainment to increase the motivation of learning and cognitive learning outcomes learner.

\section{Procedure}

This research procedure consists of 4 phases i.e. phase define, design, develop, and disseminate. Stage define in this study consists of an initial analysis, analysis of the learners, analysis tasks, concepts, analysis and formulation of learning objectives. Stage design consists of a drafting instrument, selection, selection of media formats, and the initial draft (draft I). Develop phase consists of a review of the product by the supervising professor, validation by expert lecturers and teachers of the IPA, the revision of the draft II, and test the product. Disseminate stages carried out by handing the products development to schools, presentations during the tests, and writing a scientific article.

Data, Instruments, and Data collection Techniques

There are several instruments used in this research, including sheet validation device learning IPA, now the response of learners towards learning Science Edutainment, learning motivation of students now, reserved pretest and posttest, and keterlaksanaan observation sheet learning Science Edutainment.

\section{Data Analysis Techniques}

Technique of data analysis used in this study are as follows.

1. Analysis Of The Feasibility Of The Device Learning IPA

Data obtained from the results of the validation are analyzed to find out the feasibility of the device with the IPA learning based on table 1.

Table 1. Conversion of the actual Scale value Score Four

\begin{tabular}{ccc}
\hline Score Range & $\begin{array}{c}\text { The } \\
\text { value of } \\
\text { the }\end{array}$ & Category \\
\hline $\mathrm{SBx}+1>\boldsymbol{X}$ & A & $\begin{array}{l}\text { Very } \\
\text { Good }\end{array}$ \\
\hline$\overline{\boldsymbol{x}}+\mathbf{1} . \boldsymbol{S B} \boldsymbol{B}>\boldsymbol{X} \geq \overline{\boldsymbol{x}}$ & B & Good \\
\hline$\overline{\boldsymbol{x}}>\boldsymbol{X} \geq \overline{\boldsymbol{x}}-\mathbf{1 . S B \boldsymbol { x }}$ & C & Enough \\
\hline $\boldsymbol{X}<\overline{\boldsymbol{x}}-\mathbf{1 . S B \boldsymbol { x }}$ & D & Less \\
\hline
\end{tabular}

(Mardapi, 2008: 123)

2. Analysis of the response of the students towards Learning Science Edutainment

The results of the response of the students to be more easily understood, then the conversion is done with based on table 2 .
Table 2. The qualitative Value of conversion terms being Quantitative

\begin{tabular}{lcc}
\hline \multirow{2}{*}{\multicolumn{1}{c}{ Criteria }} & \multicolumn{2}{c}{ Score Statements } \\
\cline { 2 - 3 } & Positive & Negative \\
\hline Strongly Agree (SS) & 4 & 1 \\
\hline Agree (S) & 3 & 2 \\
\hline Disagree (TS) & 2 & 3 \\
\hline Strongly Disagree & 1 & 4 \\
(STS) & &
\end{tabular}

(STS)

(Widoyoko, 2009: 236)

Furthermore, the score obtained were converted to a scale appropriate qualitative table 1.

3. Analysis Of The Improvement Of The Learning Motivation Of Students

The results of the now motivated learners to be more easily understood, then the conversion is done with based on table 2 .

Furthermore the percentage value is changed to the value of the scale category five with the following conditions.

Table 3. The Conversion Percentage Of The Motivation Of Learning

\begin{tabular}{ll}
\hline \multicolumn{1}{c}{ Percentage $(\%)$} & \multicolumn{1}{c}{ Category } \\
\hline$>80$ & Very Good \\
\hline $60-80$ & Good \\
\hline $40-60$ & Enough \\
\hline $20-40$ & Less \\
\hline$\leq 20$ & Very Less \\
\hline
\end{tabular}

(Mardapi, 2008: 242)

4. Analysis Of Improvement Of Cognitive Learning Results Students

Score of pretest and posttest were analyzed using the following equation.

$$
\text { gain score }=\frac{\text { skor posttest }- \text { skor pretest }}{\text { skor maksimal }- \text { skor pretest }}
$$

Belajr results of cognitive improvement criteria can be determined in accordance with the criteria in the table 4 .

Table 4. The Criteria Increased Cognitive Learning Results

\begin{tabular}{cc}
\hline Limitation & Category \\
\hline $\mathrm{g}>0.7$ & High \\
\hline $\mathrm{g} \leq 0.30 .7$ & Low \\
\hline $\mathrm{g}<0,3></ 0,3>$ & Is being \\
\hline
\end{tabular}

(Hake, 1999: 1)

\section{THE RESULTS OF THE RESEARCH AND THE DISCUSSION}

1. The Feasibility Of The Product Device Learning IPA

IPA learning device developed by validation tests then conducted two expert lecturers and two teachers in the IPA as a 
practitioner. This validation test aims to get suggestions and criticisms so that the device meets the criteria developed learning feasible for use in learning. Learning devices developed consists of a syllabus, RPP, LKPD, media, and assessment instruments. Aspects are assessed on the syllabus and RPP in accordance with indicators that are present in Standard process of Permendikbud No. 22 Year 2016, while the aspects assessed at LKPD include didactic terms, the terms of construction, technical terms, and the emergence of characteristics of a Science Edutainment.

Based on the results of the assessment of the overall device learning by the validator, scores obtained indicate that the entire device learning IPA stated worth with excellent category (A). The following is a table of the results of assessment of learning devices in the scale 4 .

Table 6. The Results Of The Assessment Of Learning Devices

\begin{tabular}{|l|l|c|c|c|}
\hline \multirow{2}{*}{ No. } & \multirow{2}{*}{$\begin{array}{c}\text { Learning } \\
\text { Devices }\end{array}$} & $\begin{array}{c}\text { Assessment } \\
\text { Lectur } \\
\text { ers }\end{array}$ & $\begin{array}{c}\text { Teach } \\
\text { er IPA }\end{array}$ & $\begin{array}{c}\text { Kate- } \\
\text { gori }\end{array}$ \\
\hline 1. & Syllabus & 3.8 & 3.92 & A \\
\hline 2. & RPP & 3.82 & 3.89 & A \\
\hline 3. & LKPD & 3.82 & 3.82 & A \\
\hline
\end{tabular}

The feasibility of such learning devices supported with learning Science Edutainment keterlaksanaan of $100 \%$ with very good category (A).

2. The response of the students towards Learning Science Edutainment

The response of the students towards learning Science Edutainment measured using question form provided at the end of learning. The response of the students towards the learning of Science material aspect of Edutainment, the media, Science Learning, Edutainment, assessment instruments, and LKPD. The response gets an average of $62.94 \%$ by category (B).

3. Improvement Of Learning Motivation Of Learners

Increase in motivation study measured using instruments now given before and after the learning learning using learning Science Edutainment. The learning motivation of the now developed based on indicators of motivation of learning i.e. attention (attention), relevance (relevance), self confidence (confidence), and satisfaction (satisfaction).

Percentage of learning motivation of learners before following learning Science Edutainment question form method is $58.92 \%$ whereas the percentage of learning motivation after following learning Science Edutainment of 69.65 per cent. From these data, then increased the motivation of learning to learners is of $10.73 \%$. Overall, the four aspects of motivation study measured increased i.e. aspects of attention of 11.77 percent, $10.98 \%$ of the relevance of aspects, aspects of the self-assurance of $8.8 \%$, and the satisfaction of $11.4 \%$. Percentage increase in learning motivation diagram with the method now can be seen in Figure 1.

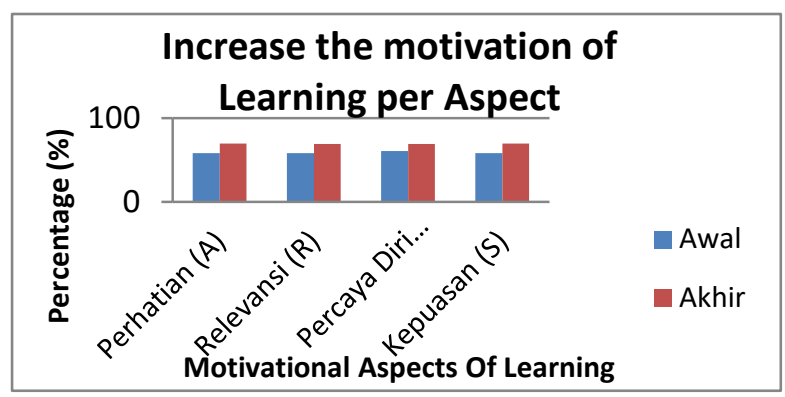

Figure 1. Increase the motivation of Learning per Aspect

Calculation based on the results of the question form of motivation to learn, there is an increase in the motivation of learning learning after a Science Edutainment. This happens because the learning Science interesting and exciting Series is designed so that students are motivated to follow learning IPA.

4. Improvement Of Cognitive Learning Results Students

Improvement of cognitive learning outcomes measured by using pretest and posttest problem. Reserved pretest given prior learning and reserved posttest given after learning to use the device in the Science-based learning, Edutainment. Upon calculation, obtained an average value of 78.87 pretest and posttest average amounted to 94.31 . Based on that data, obtained by increasing cognitive value of 0.73 and included in the category. Pretest and posttest results diagrams can be seen in Figure 2.

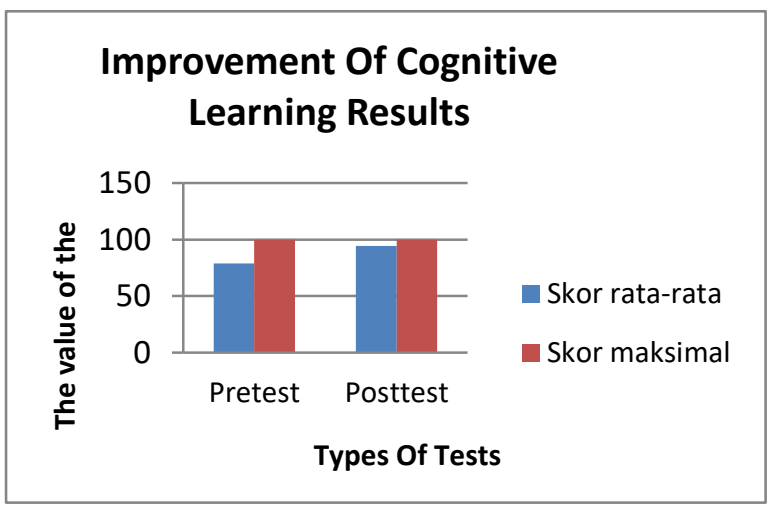

Figure 2. Graphic Enhancement Of Cognitive Learning Results

Based on the calculation from the results of pretest and posttest, there is an increase in cognitive learning outcomes after students follow 
the learning Science Edutainment. This occurs because by engaging in interesting and exciting learning, learners will more easily understand what they learn.

\section{SUMMARY AND ADVICE}

\section{Summary}

1. The device has generated learning IPA-based science edutainment on the theme of Global warming for increasing motivation and cognitive learning outcomes students who meet eligibility based on the assessment that has been undertaken by the validator by acquiring excellent category (A).

2. The response of the students towards the Science Learning through Edutainment question form response scores $62.94 \%$ average and is included in the category either (B).

3. Learning IPA using science-based learning, edutainment on the theme of Global warming can increase learning motivation of learners from the category simply be good categories with an increase of $10.74 \%$.

4. Learning IPA using Science-based learning, Edutainment learning outcomes can improve cognitive learners by acquiring "score gain of 0.73 and included in the category.

\section{Advice}

1. We recommend that prior to charging the now the motivation of learning, learners are given an understanding of the importance of filling the question form.

2. For subsequent researchers, should select the learning materials bepotensi to be developed into various types of activities that can accentuate the hallmark of Science Edutainment.

3. For subsequent researchers, should select a Science Edutainment as major problems will be examined or developed.

\section{BIBLIOGRAPHY}

Hake, Richard R. (1999). Analyzing Change/Gain Scores. Accessed from http://www.physics.indiana.edu/ sdi/AnalyzingC hange-Gain.pdf on March 20, 2017.

Mardapi, D. (2008). Teknik Penyusunan Instrumen Tes dan Nontes. Yogyakarta: Mitra Cendekia Press.

Purwanto, N. (2012). Prinsip-prinsip dan Teknik Evaluasi Pembelajaran. Bandung: Rosdakarya.
Sivasailam, T., Semmel, D.S., \& Semmel, Myocardial Infarction And (1974). Instructional Development for Training Teachers of Exceptional Children. Bloomington: Indiana University.

Widoyoko, E.P. (2009). Evaluasi Program Pembelajaran. Yogyakarta: Pustaka Pelajar. 